\title{
The effect of religiosity on organizational citizenship behavior and affective commitment: a case of Islamic higher education institution
}

\author{
Wiwik Yulistia Ningsih \\ Faculty of Business and Economics, Universitas Muhammadiyah Yogyakarta, \\ Yogyakarta, Indonesia. \\ Corresponding author: wiwikyulis85@gmail.com
}

Article History

Received, 6 November 2019 Revised 1, 25 November 2019 Revised 2, 28 November 2019 Accepted, 10 December 2019

\begin{abstract}
Purpose: This study aims to analyze the effect of religiosity on organizational citizenship behavior and affective commitment at the Universitas Muhammadiyah Yogyakarta as an Islamic higher education institution.

Design: Respondents of this study were 96 permanent faculty staffs. This study used questionnaire as data collection techniques. The data analysis method used is multiple linear regression with SPSS as an analysis tool.

Findings: The results of this study indicate that religiosity has a significant positive effect on organizational citizenship behavior, religiosity has a significant positive effect on affective commitment and affective commitment has a significant positive effect on organizational citizenship behavior

Originality/value: Studies related to organizational citizenship of Islamic institution are still limited.

Keywords: affective commitment, Islamic institution, organizational citizenship behavior, religiosity

Cite this:

Ningsih, W.Y. (2019). The effect of religiosity on organizational citizenship behavior and affective commitment: a case of Islamic higher education institution. Asian JournalofIslamicManagement,1(2),109-115. DOI: 10.1108/AJIM.vol1.iss2.art5

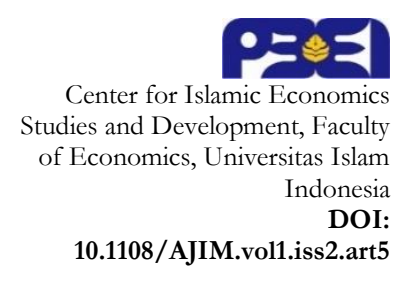

\section{Introduction}

University has become a place of study for a higher level. Not only state-owned university that has good quality, currently private universities are also able to compete and provide good quality. Every university has a goal which is to produce good and quality graduates in their respective fields and at present many companies are bound by cooperation with universities to recruit quality graduates so that they can join to become part of the company. This is inseparable from the role of human resources in each university, not only in the teaching staff but also in the supporting staff. Basically, every organization wants employees who can work optimally without leaving the values of religiosity as a guide to work. The level of religiosity possessed by each employee will have a direct influence on the employee's behavior, for example the emergence of organizational citizenship behavior commonly referred to good behavior such as voluntary and please help. This is also expected to be able to bring employee loyalty to the organization such as commitment towards the organization. 
Religiosity is the part of self that reflects a person with the values of religiosity obtained from the value of religiosity during his life (Yanuarti, 2018). The level of employee religiosity can have an impact on the employee's behavior. Good or bad behavior will affect the sustainability of the organization. The progress of the organization is supported by good behavior from employees, one of which is organizational citizenship behavior. Organizational Behavior Citizenship Behavior (OCB) is an action that is carried out of its own desires that can help the effectiveness of the organization, an example of this OCB behavior is helping the work of a teammate (Robbins \& Coulter, 2010). Unal (2014) states that affective commitment is influential because an individual's emotional closeness will make one to be more involved in the organization without coercion from anyone. (Ni'mah \& Wulansari, 2018) That way he will do his job with positive feelings and volunteering to help.

Thus, the purposes of this research are:

a. To find out whether religiosity positively affects organizational citizenship behavior

b. To find out whether religiosity positively affects affective commitment

c. To find out whether affective commitment positively influences organizational citizenship behavior

\section{Literature Review}

\section{Organizational Citizenship Behavior}

According to Organ (1988), Organizational Citizenship Behavior is employee behavior to improve performance effectiveness. Podsakoff, et al. (1990) also found that there are dimensions of organizational citizenship behavior, namely: Altruism (behavior helps in dealing with problems with those experienced by co-workers with the wishes of themselves), conscientiousness (behavior that exceeds the minimum standard limits such as compliance with regulations, rest periods done on their own free will), sportsmanship (employee tolerance behavior, behavior that does not exaggerate the problem, humble and not easy to complain), courtesy (behavior with desires itself to avoid work problems by maintaining good relations between coworkers), civic virtue (employee behavior by showing a sense of responsibility towards the company and concern for the sustainability of the company).

\section{Religiosity}

According to Palupi \& Tjahjono (2016) religiosity is a picture of the pattern of human relations with God and relationships with those around him, the level of individual religiosity will have an impact on individual behavior. Jianfeng, et al. (2009) explained that religiosity refers to the belief system and practice of religious rituals that are used to facilitate one's relationship with God and maintain relationships with others. Palupi \& Tjahjono (2016) explain that the relationship is in line with the concepts of bablumminallab (one's relationship with God) and bablumminanas (one's relationship with fellow human beings) in Islamic studies. Allah teaches Muslims to pay attention to their relationship with God and other humans.

\section{Affective Commitments}

Organizational commitment is a psychological condition in the form of wants, needs, or sense of individual obligation to maintain membership in the organization (Allen \& Meyer, 1990) also said that there are three dimensions of organizational commitment, namely: affective commitment, continuance commitment and normative commitment. Employees with high affective commitment tend to be more often involved in organizational activities and have a desire to stay organized (Rhoades, Eisenberger, \& Armeli, 2001). Affective Commitment is the engagement of employees in organizations with the same values, goals and emotions (Palupi \& Tjahjono, 2016). 


\section{Research Model}

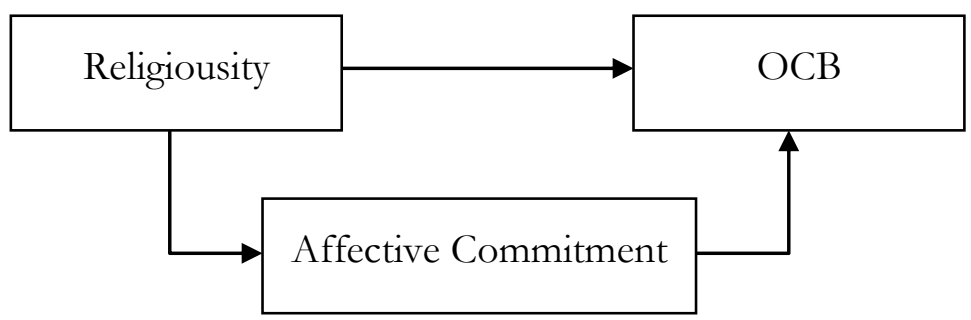

Figure 1. Research Model

Based on Figure 1, this research has three hypotheses:

a. H1: Religiosity has a positive effect on organizational citizenship behavior

b. H2: Religiosity has a positive effect on affective commitment

c. H3: Affective commitment has a positive effect on organizational citizenship behavior

\section{Methods}

\section{Object and Subject of Research}

This research took place at Universitas Muhammadiyah Yogyakarta, which is located on the road Brawijaya, Kasihan, Bantul, Yogyakarta. The subject used in this study are permanent staffs of Faculty of Education with a total of 96 people.

\section{Types of Data}

In this study, the type of data used is primary data, by distributing questionnaires directly to respondents.

\section{Test Instrument Data}

\section{Validity test}

Validity test to determine whether the instrument items are valid and can be tested to the next stages. It is considered valid if $r$ count $>r$ table then the statement is valid with a significant level of 5\% (Sekaran \& Bougie, 2017). In this study the validity test using SPSS 22.00.

\section{Reliability test}

Reliability tests are carried out to prove the accuracy, consistency, and accuracy of the instrument in measuring constructs. This test is to determine whether the data provided by respondents is true and can be trusted. In this study using SPSS 22.00 by looking at the reliability coefficient on alpha, it can be said to be reliable if the Cronbach alpha value is greater than 0.6 (Sekaran \& Bougie, 2017).

\section{Classical assumption test}

a. Normality test is used to determine whether the regression of independent variables and dependent variables contribute to each other or not (Ghozali, 2016). This study uses Kolmogrov-Smirnov (K-S) non-parametric normality test. A variable is said to be normal if the significance value $>0.05$.

b. Multicollinearity test aims to determine whether the regression model found a correlation with the independent variable (Ghozali, 2016).

c. Heteroscedasticity Test aims to find out whether in a regression model there is an unequal variance from the residuals of one observation to another. However, if the observations are 
different, it is called heteroscedasticity, a good model is a model that does not occur heteroscedasticity (Ghozali, 2016).

\section{Hypothesis test}

a. Simple Linear Analysis

It is an approach for modeling the relationship between one dependent variable and one independent variable. Simple linear equations include:

Explanation :

\section{$\mathrm{Y}=\mathrm{A}+\mathrm{BX}+\mathrm{e}$}

Y: Dependent variable

$\mathrm{X}$ : Independent variable

A: Intercept/constant

B: Regression coefficient

e: Residual/error

b. Multiple Linear Analysis

In multiple linear regression, there are more than one independent variables. In this research, it requires the study of various variables that can affect another variable.

Multiple linear equations include:

Explanation :

$$
\mathbf{Y}=\boldsymbol{\beta}_{0}+\boldsymbol{\beta}_{1} \mathbf{X}_{1}+\boldsymbol{\beta}_{2} \mathbf{X}_{2}+\boldsymbol{\beta}_{3} \mathbf{X}_{3}+\mathbf{e}
$$

\begin{tabular}{|c|c|}
\hline Y & $=$ Organizational citizenship behavior \\
\hline $\mathrm{X} 1$ & $=$ Religiosity \\
\hline $\mathrm{X} 2$ & $=$ Affective commitment \\
\hline B1 $\beta 2 \beta 3$ & $=$ Regression coefficient \\
\hline B0 & $=$ Regression constant \\
\hline
\end{tabular}

\section{Results and Discussion}

This study aims to analyze the effect of religiosity on organizational citizenship behavior and affective commitment. The data in this study were 96 respondents of permanent education staff at the Universitas Muhammadiyah Yogyakarta. The results of the questionnaire were examined through validity and reliability tests. After that, we used descriptive statistical analysis, data analysis methods, classical assumptions analysis and regression analysis funds. Data analysis in this study used SPSS 22.0.

\section{Data Quality Test}

Validity test used Pearson Product Moment Correlation by calculating the correlation between the score of each question item on its total score. Religiosity variable consists of 10 question items, organizational citizenship behavior consists of 24 question items and affective commitment consists of 8 question items. The results of this test use SPSS version 22.0 and show the results that the Pearson correlation value of each question item shows significant results. So it can be concluded that each question item from each variable is valid and this study deserves further analysis.

Table 1. Reliability Test

\begin{tabular}{lc}
\hline Variable & Cronbach's Alpha \\
\hline Religiosity & 0,709 \\
Organizational Citizenship Behavior & 0,721 \\
Affective Commitment & 0,632 \\
\hline
\end{tabular}


The reliability test can be seen on Table 1 . The Cronbach's alpha value of the religiosity is 0.709 , organizational citizenship behavior is 0.721 and affective commitment is 0.632 . Thus, this study can be said to be reliable.

\section{Analysis of Classical Assumptions}

The Normalilty test uses the Kolgomorov Smirnov method. It shows the a value of 0.083 which is greater than 0.05 . Thus, it can be concluded that the instrument is normally distributed.

Multicollinearity test is to test the presence or absence of multicollinearity symptoms by looking at the value of tolerance and VIF. If the VIF value is less than 10, it does not have multicollinearity symptoms. Conversely, if the VIF value is greater than 10 , there are multicollinearity symptoms.

Table 2. Multicollinearity Test

\begin{tabular}{llll}
\hline Variable & VIF & Tolerance & Explanation \\
\hline Religiosity & 1,043 & 0,959 & No Multicollinearity Occurs \\
Affective Commitment & 1,043 & 0,959 & No Multicollinearity Occurs \\
\hline
\end{tabular}

Based on Table 2, this research has a VIF value of 1.043, which means that there are no symptoms of multicollinearity.

Heteroscedasticity test with scatterplot method shows that it has no patterned and are located uncertainly and are spread above and below the number 0 . So it can be concluded that there is no heteroscedasticity.

\section{Regression Analysis}

Table 3. Regression Analysis

\begin{tabular}{llll}
\hline & Religiosity - OCB & $\begin{array}{l}\text { Religiosity - Affective } \\
\text { Commitment }\end{array}$ & $\begin{array}{l}\text { Affective Commitment- } \\
\text { OCB }\end{array}$ \\
\hline B & 0,391 & 0,203 & 0,192 \\
Sig & 0,000 & 0,047 & 0,043 \\
\hline
\end{tabular}

Based on Table 3, the result of the hypothesis tests are:

Hypothesis 1: The result of multiple regression analysis on religiosity towards OCB shows a $\beta$ value of 0.391 , which means that Religiosity has a positive effect on OCB. In addition to that, the significance value of 0,000 , which means that the value $<0.05$. Therefore, $\mathrm{H} 1$ is "accepted" and supported by the research of Awuni \& Tanko (2019) which also shows that religiosity has a positive influence on organizational citizenship behavior. Influence is shown as they feel that Allah SW'T is present in their work and they will feel happy if they can benefit the environment, it will have a positive influence where this will increase awareness to behave in organizational citizenship behavior, such as helping the work of other employees.

Hypothesis 2: The result of multiple regression analysis on religiosity towards affective commitment shows a $\beta$ value of 0.203 , which means that religiosity has a positive effect on affective commitment. The significance value is 0.047 which means that the value $<0.05$. It can be concluded that $\mathrm{H} 2$ is "accepted" and the results of this study are also supported by research of Farrukh, Ying2, \& Omar (2016) which states that religiosity has a positive effect on affective commitment. This influence is shown employees who have a high level of religiosity will do their work as part of worship.

Hypothesis 3: The result of multiple regression analysis on affective commitment to OCB shows a $\beta$ value of 0.192 , which means that affective commitment has a positive effect on OCB. 
The significance value is 0.043 which means that the value $<0.05$. It can be concluded that $\mathrm{H} 3$ is "accepted" and supported by research of Tjahjono, Prasetyo, \& Palupi (2018) which states that affective commitment has a significant positive effect on organizational citizenship behavior. This influence is shown by the significant significance of the Universitas Muhammadiyah Yogyakarta for employees, which has a positive impact that is that it will always do something that has a good impact on the organization such as attending meetings that are not mandatory but considered important and will even attend activities carried out by outsiders to improve the image of the organization, do something good for the achievement of organizational goals.

\section{Conclusion and Suggestion}

Based on the previous discussion, it can be concluded that religiosity has a positive effect on organizational citizenship behavior and affective commitment. In addition to that, affective commitment also has a positive influence on organizational citizenship behavior.

For further study, the researchers can expand the scope of research by adding research subjects and other variables. In addition to that, the further researchers can also use other data collection technique in order to improve the research results.

\section{References}

Ahmed, N. O. A., Ying, C. W., \& Farrukh, M. (2016). Organizational commitment Does religiosity matter.

Allen, N. J., \& Meyer, J. P. (1990). The measurement and antecedents of affective, continuance and normative commitment to the organization. Journal of occupational psychology, 63(1), 118.

Farrukh, M., Ying2, C. W., \& Omar, N. (2016). Organizational commitment: Does religiosity matter? Cogent Business \& Management.

Ghozali, I. (2016). Aplikasi Analisis Multivariete Dengan Program IBM SPSS 23 (Edisi 8). Semarang: Universitas Diponegoro.

Jianfeng, L., Hongping, L., \& Lanying, D. (2009, December). The effect of religiosity on shopping behavior: an exploratory study during the transitional period in China. In 2009 International Conference on Information Management, Innovation Management and Industrial Engineering (Vol. 2, pp. 31-34). IEEE.

Ni'mah, I., \& Wulansari, N. A. (2018). Pengaruh Person-Organization Fit pada Komitmen Afektif yang Dimediasi oleh Nilai-Nilai Kolektif. Management Analysis Journal, 7(1), 38-49.

Organ, D. W. (1988). Organizational citizenship behavior: The good soldier syndrome. Lexington Books/DC Heath and Com.

Palupi, M., \& Tjahjono, H. K. (2016, May). A model of religiousity and organizational justice: the impact on commitment and dysfunctional behavior. In Proceedings of the 27th IBMA Conference.

Podsakoff, P. M., MacKenzie, S. B., Moorman, R. H., \& Fetter, R. (1990). Transformational leader behaviors and their effects on followers' trust in leader, satisfaction, and organizational citizenship behaviors. The leadership quarterly, 1(2), 107-142.

Rhoades, L., Eisenberger, R., \& Armeli, S. (2001). Affective commitment to the organization: The contribution of perceived organizational support. Journal of applied psychology, 86(5), 825.

Robbins, S. P., \& Coulter, M. (2010). Manajemen Edisi Kesepulub Jilid 2. Jakarta: Erlangga. 
Sekaran, U., \& Bougie, R. (2017). Metode Penelitian untuk Bisnis (Vol. II). Jakarta: Salemba Empat. Tjahjono, H. K. (2015). Metode Penelitian Bisnis. Yogyakarta: VSM MM UMY.

Tjahjono, H. K., Prasetyo, F., \& Palupi, M. (2018). Kepemimpinan Transformasional Pada Organizational Citizenship Behavior Dan Komitmen Afektif. Jurnal Manajemen dan Pemasaran Jasa, 11(2), 217-232..

Unal, Z. M. (2014). Does Affective Commitment Mediate the Relationship between PersonOrganization Fit and Organizational Identification?. International Journal of Academic Research in Business and Social Sciences, 4(3), 270-283.

Yanuarti, E. (2018). Pengaruh Sikap Religiusitas Terhadap Perilaku Hidup Bersih Dan Sehat Masyarakat Kabupaten Rejang Lebong. Jurnal Kajian Keislaman dan Kemasyarakatan. Sekolah Tinggi Agama Islam Negeri Curup, 3(1). 